\title{
THE IMPACT OF VARIETIES OF JEWISH EDUCATION UPON JEWISH IDENTITY: AN INTER-GENERATIONAL PERSPECTIVE*
}

\author{
Steven M. Cohen \\ The Melton Centre for Jewish Education \\ The Hebrew University of Jerusalem \\ (Contemporary Jewry v. 16 1995)
}

This study assesses the impact of several forms of Jewish education upon composite measures of Jewish identity for teenagers and for their parents. The analysis controls for each generation's parents' Jewishness as well as for other factors. All forms of Jewish edcuation, except Sunday school, are associated with higher levels of Jewish identity in both generations. The putative effects of day school, including nonOrthodox day schools, are especially pronounced. Among adults, all forms of Jewish education, except Sunday school, are associated with lower rates of intermarriage. The likely impact of youth groups, Israel travel on intermarriage rates are rather small.

Like other American religious and ethnic groups, American Jews have developed a multi-faceted educational system embracing both schools and programs of non-formal education. The more widely used instruments of children's Jewish education include Sunday schools, afternoon schools, day schools, summer camps, youth groups, and Israel travel programs. In their entirety, these institutions employ tens of thousands of educators and support staff, at an annual cost sometimes estimated at two billion dollars (Commission on Jewish Education in North America 1990).

If for no other reason, the sheer size of this endeavor prompts one to ask: To what extent does this voluntary, sectarian educational system succeed in what many regard as its chief purpose, that of transmitting, shaping, and strengthening Jewish identity among its students as they mature? In simple terms, does Jewish education make a difference, and, if so, how, and in what ways, and for whom?

Obviously, this question has direct implications for the future of American Jewry, in particular, its prospects of remaining a distinctive and cohesive ethnic and religious group. Recent reports of high and mounting rates of Jewish-Gentile marriage (Kosmin, Goldstein, Waksberg, Lerer, Keysar and Scheckner 1991) have led many to 
speculate that large numbers of American Jews-or, more precisely, their offspring - will fail to identify as such, or will do so in only the most superficial fashion. In response, many Jewish parents and the organized Jewish community are pinning their hopes for "Jewish continuity" upon the Jewish educational system.

Well before the most recent wave of attention to an increased intermarriage rate, American Jews had become less concerned about obtaining acceptance as Americans and more concerned about their families' Jewish continuity (Cohen and Fein 1985). As a result of the increasing concern with Jewish group continuity and diminished anxieties about self-segregation, Jews came to increasingly use more intensive forms of Jewish education such as day schools and Israel youth travel, both of which maintain significantly higher rates of participation than in the mid-1960s. In this context, the effectiveness of this education system bears directly upon the question of the very ability of American Jewry to maintain its demographic size and its cultural distinctiveness.

On a larger plane, this question also speaks to our understanding of American ethnicity and American religious life. With regard to ethnicity, much of the recent social scientific literature casts doubt on whether middle-class white ethnic groups will persist as culturally distinctive and socially cohesive communities (see Alba 1985 and 1990; Lieberson and Waters 1988). Gans (1979) has advanced the widely cited notion of "symbolic ethnicity," (and, most recently, "symbolic religiosity" (1994)) which sees American white ethnics as maintaining only a symbolic but not substantive link to their particular ethnic sub-cultures and sub-communities.

In contrast, in the 1960s and 1970s, several scholars had suggested that American ethnic groups manage to sustain and reinvent ethnic cultures in ways suitable to contemporary America (Glazer and Moynihan 1963 and 1975; Greeley 1974; Novak 1971). The validity of this "Cultural Pluralist" perspective (or others close to it) ultimately rests upon current directions now underway among white, economically comfortable ethnic groups, among which Jews are a critical case in point.

Unlike many white ethnic groups who have experienced what may be called ethnic erosion, American Jews have seemingly resisted assimilatory trends, at least until recently. Signs of ethnic dissolution among American Jews-as would be embodied in evidence of a failing Jewish educational system-would certainly strengthen the case of "Melting Pot" and "symbolic ethnicity" theorists. For, if the Jews 
cannot persist as a socially cohesive and culturally distinctive group, how likely is it that Poles, Italians and others will do so?

With respect to American religious life, the recent literature points to a quarter century of decline in the more liberal churches (Roof and McKinney 1987; Finke and Stark 1992). It can be argued that these sorts of churches resemble Reform and Conservative Judaism, the two most populous branches of American Judaism. If the trends of the larger society do, in fact, embrace American Judaism, then we would expect to witness declines in Jewish religious practice and affiliation, as well as an increasingly ineffective religious education system.

To assess the impact of various forms of Jewish education upon group identity (a term used in an intentionally loose fashion throughout this paper), this study examines two contemporary groups of American Jews: younger to middle-aged adults, and, where available, their teenage children. With respect to these individuals, it explores the extent to which instruments of Jewish education have generally produced the results widely sought after by various stakeholders in the Jewish educational system.

A noteworthy handful of quantitative, empirical studies of American Jewry over the last quarter century have explored the impact of Jewish education upon Jewish identity (or portions thereof) in fairly similar ways (Bock 1974; Cohen 1974 and 1988; Dashefsky and Shapiro 1974; Fishman 1987; Fishman and Goldstein 1993; Himmelfarb 1974 and 1979; Lipset 1994; Mayer 1993; Rimor and Katz 1993). They developed quantitative measures of current Jewish identity among adults, related them to previous Jewish schooling, and controlled for relevant background factors, in particular, the Jewishness of the home (i.e., the respondents' parents). Taken in their totality, these studies agree on some key issues, disagree on others, leave some critical questions unanswered, and generally suffer from a particular and consequential methodological shortcoming.

Consistent with Greeley and Rossi's influential research on American Catholic schooling (1966), most of these studies agree that the Jewish involvement of the home or the parents exerts more influence than the school upon levels of Jewish involvement as an adult. Some social scientists and educators have argued that with respect to Jewish values and commitment, schools usually can do little except to reinforce that which has been fostered by Jewishly involved parents.

The second key point of consensus entails the intensity of Jewish schooling. All studies on the matter agree that more Jewish schooling - whether measured in terms of years or total number of hours in 
Jewish studies-is associated with higher levels of subsequent adult Jewish involvement.

One key area of disagreement concerns the effectiveness of parttime Jewish schools (those meeting in the weekday afternoons and on Sunday mornings). Several studies concluded that controlling for parental Jewish involvement, alumni of part-time Jewish schooling hardly differed, if at all, from those with no Jewish schooling on most measures of adult involvement (e.g., Bock 1974; Himmelfarb 1974; 1979).

In contrast, analysis of the 1981 Greater New York Jewish Population Study, a data set similar in structure and content to those used in previous studies of Jewish schooling, demonstrated that failure to control for sex obscures the impact of part-time Jewish schooling (Cohen 1988). To elaborate, in the earlier decades of the twentieth century, many Jewish daughters from stronger Jewish home and community environments received no formal Jewish schooling. (The gap between the Jewish educational experiences of girls and boys has closed considerably since then.) As a result, the no-school group for Jewish adults who were children prior to 1950 contains a good number of Jewishly involved women. Their presence elevates the measures of Jewish involvement for this group, effectively obliterating the differences with the alumni of part-time schools. Separating the men from the women allowed for the emergence of a moderate impact of part-time schools when compared with no-education groups of the same sex. Of all the half dozen or so studies in the field, this is the only one that argues in favor of the presence of generally effective part-time schools. Obviously, the question of their effectiveness remains open.

Although several studies have examined the impact of Jewish schools, hardly any have touched upon the parallel effects of informal Jewish education. Few, if any, quantitative studies have sought to examine the long-term impact of summer camps, youth groups, and travel to Israel by young people on adult Jewish identity (for an exception, see Horowitz 1993; also see Goldstein and Fishman 1993). This gap in the research literature is all the more glaring in the case of the "Israel experience" (organized trips by adolescents to Israel, generally for 4-8 weeks during the summer months). Israel youth travel has taken on increased policy significance in just the last few years. American Jewish philanthropists and their agencies have placed increasing emphasis upon this particular educational instrument as a way of diminishing future rates of intermarriage and assimilation among today's Jewish young people. No study has yet examined the 
assumption that trips to Israel eventually strengthen Jewish involvement generally, or that they increase the chances that participants will marry Jews, more specifically.

Even were the previous studies conclusive, concurring and comprehensive, the extent of change in American Jewry and in Jewish education calls into question the relevance of prior research for understanding the recent or current impact of Jewish education. Among the notable changes in Jewish education are the growth in day school enrollment and consequent change in the character of day school students. Once "day school" referred almost exclusively to Orthodox sponsored institutions serving youngsters from Orthodox homes. Today, the number of youngsters who at some point receive some day school education outside of Orthodoxy now roughly equals the number who ever attend Orthodox yeshivas and day schools (see Table 1 for the rates in the two generations in this study). Whereas travel to Israel prior to 1968 was a relatively rare occurrence for a Jewish adolescent, the last quarter century has seen thousands of such youngsters participate in well-established, highly structured, and highly supervised organized programs offering a wide range of activities and ideological frameworks. Since most of the adults in this study had attained age 16 by 1968 , it is not all that surprising to learn that $14 \%$ of them had

Table 1. Percetage of Participation in Schools and Informal Programs for Adults and Teenagers

\begin{tabular}{lcc}
\hline \hline & Adults & Teenagers \\
\hline Most Intensive Form of Jewish Schooling & & \\
& & \\
Orthodox Day School: 5+ years & 6 & 6 \\
Other Day School: 5+ years & 1 & 6 \\
Part-Time School: 3+ years & 40 & 41 \\
Sunday School: 3+ years & 25 & 21 \\
None or only tutoring & 28 & 25 \\
& & \\
Youth Group & 58 & 55 \\
Israel Travel & 14 & $19^{\mathrm{b}}$ \\
\hline
\end{tabular}

- Includes travel to Israel under private auspices as well as in organized groups.

b Calculated only for teenagers $16-17$ years old. 
visited Israel in their youth; reflecting the rise in adolescent Israel travel, an even greater proportion (19\%) of their children age 16 and 17 had been to Israel. (Horowitz (1993) also finds a clear rise in Israel travel among younger New York area Jews.)

One of the most significant relevant developments in the last quarter century is the sharp rise in Jewish-Gentile marriage. The proportion of Jews marrying non-Jews who do not convert to Judaism has risen from over $20 \%$ in late 1960 s to over $40 \%$ in most recent years (see Cohen 1994 and Kosmin et al. 1991 for alternative estimates of the recent mixed marriage rate in the National Jewish Population Study data), bearing implications for Jewish education on several levels. Conceivably, the environment of a high rate of intermarriage may limit the effectiveness of Jewish education. For those who intermarry, the presence of a non-Jewish spouse may make it all but impossible for the former participants in Jewish schools, camps, youth groups and Israel trips to put their education into practice; and for the entire population, the awareness of a high intermarriage rate may subtly undercut and delegitimize the distinctive and sometimes particularistic teachings of Judaism and Jewish education.

Given the sharply lower rates of Jewish involvement on the part of mixed married as contrasted with in-married Jews, any contemporary analysis of the impact of Jewish education needs to consider the two populations separately, as the impact of Jewish education may well be limited to the in-married. Moreover, and not least, is the question of whether Jewish education directly affects the chances of marrying within the group.

A methodological complication has justifiably limited the readiness of previous researchers to claim that they have demonstrated a discernable impact of childhood Jewish education upon adult Jewish identity. Several of the previous studies had at their disposable relatively little information regarding the childhood home of the respondents. The data sets analyzed certainly contained a large number of items on adults' current Jewish involvement, as well as adequate information on their childhood Jewish schooling. But many studies have been forced to rely on only a few questions pertaining to their parents' Jewish involvement.

One case in point is the 1990 National Jewish Population Study (NJPS), the widely cited random sample survey of American Jews sponsored by the Council of Jewish Federations (Kosmin et al., 1991). In just the last two years, these data have generated at least five studies of Jewish education (Fishman and Goldsetein 1993; Goldstein and Fishman 1993; Lipset 1993; Mayer 1993; Rimor and Katz 1993). This 
highly authoritative source of data on contemporary American Jews contains only two critical pieces of information on respondents' parents: whether they were both Jewish (asked of only a third of the sample), and their Jewish denomination (Orthodox, Conservative, Reform, etc.).

In exploring the impact of different sorts of Jewish schooling upon adult Jewish involvement, the recent NJPS-based studies did their best to factor out parents' involvement. To do so, they used the items on parents' in-marriage and denomination raised to statistically assume that the alumni of all types of Jewish schools, in effect, shared parents with equal levels of Jewish involvement. Given the limitations of the NJPS data, this assumption translates into the claim that the home environments of in-married Conservative parents who chose day schools, parttime schools, Sunday schools, or no schools for their children are functionally equivalent. In point of fact, Conservative in-married couples range across a wide spectrum of Jewish involvement, one that relates strongly to choice of Jewish school for one's children. Conservative parents who sent their children to Jewish day schools in the 1960s or earlier were among a very small minority whose youngsters went to schools of Orthodox sponsorship (the prevalent form of day school at the time). In this, they clearly differed from their counterparts who sent their children to part-time schools sponsored by their Conservative synagogues.

The extent of differences among in-married Conservative parents can be illustrated by some results from this study. Of current adults who went to day schools and were raised by in-married Conservative parents, $66 \%$ reported that their parents scored "high" on an index of parental Jewish involvement (details on index construction are provided below); in, contrast, of the alumni of part-time schools, only $35 \%$ reported highly involved parents, as did just $16 \%$ of those who went to Sunday schools. Clearly, even though all were raised by in-married Conservative parents, the extent of their parents' Jewish involvement varied dramatically by intensivity of Jewish education.

Inaccuracies in measuring parental Jewish involvement in these studies tend to produce over-estimates of the impact of more intensive forms of Jewish education. To illustrate, since day schools tend to draw students from more Jewishly involved homes, failure to properly extract the impact of their greater home involvement leaves day schools artificially picking up the "credit" for producing Jewishly involved graduates that properly should be attributed to their homes.

To be sure, researchers have been well aware of these limitations and by careful choice of words, have avoided making explicit causal 
inferences. Fishman and Goldstein (1993:12) provide an apt illustration when they conclude (italics added):

The 1990 NJPS data show us the strong correlation of Jewish education and enhanced Jewish identification. ... Extensive Jewish education is definitively associated with higher measures of adult Jewish identification. Even after adjusting for denomination of Judaism in which a person is raised, extensive Jewish education is related to a greater ritual observance [and other aspects of Jewish identification].

With more comprehensive measures of parental Jewish involvement, we can feel more confident about making the types of causal inferences that are more implicit that explicit in the previous studies. This study aims to build upon and extend the previous research, addressing questions that the prior studies could not, and resolving discrepancies in their findings.

The main empirical questions addressed here are:

1) Most broadly and most fundamentally, does Jewish education during childhood affect Jewish identity, even after more fully controlling for the levels of parents' Jewish involvement and other confounding factors? To what extent do the results for adults and for teenagers confirm (or contradict) one another?

2) What are the effects of part-time Jewish schools on Jewish identity? Are they in fact negligible as previous studies have claimed?

3) Is the influence of Jewish day schools limited to the Orthodox variety that dominated in the past, or does it extend to today's increasingly popular non-Orthodox full-time schools as well?

4) Does informal Jewish education-particularly the Israel travel experienco-strongly influence subsequent Jewish involvement, as some educators and volunteer leaders have asserted?

5) How does Jewish education interact with marital choice? Does it indeed influence chances for marrying within the group? Beyond any possible influence upon choice of marriage partner, does Jewish education influence Jewish identity more among the in-married than among mixed married Jews?

\section{DATA}

The data for this study were collected via mail-back questionnaires administered in 1993 to a national sample of Jewish parents $(N=1,464)$ 
of 4-17 year old children and their teenage children, age 13-17, where present $(\mathrm{N}=615)$, by the Washington office of Market Facts, Inc. This company maintains a Consumer Mail Panel which, at the time, consisted of over a quarter million respondents who have agreed to participate in consumer research surveys.

Adult members of the Jewish subsample had identified their religion as Jewish on a previous screener questionnaire administered periodically. Adults received an eight page questionnaire, and teenagers, where available, completed a two page instrument. In both instances (parents and teenagers), approximately $70 \%$ of those receiving questionnaires returned them. Of these, a few were excluded from the analysis for reasons of ineligibility; either they failed to identify as Jews, or, in the case of the teenagers, a few were out of the specified age range.

Samples drawn from lists of individuals who have agreed to take part in frequent social surveys demand scrutiny. To what extent do we find evidence of systematic bias? To address this question, we compare the Consumer Mail Panel sample with a subsample drawn from the 1990 NJPS which may be used as a benchmark. The households selected from the NJPS for comparison met two criteria. First, a 4-17 child was present. Second, either the respondent said his/her current religion was Jewish or identified their spouse as such, in line with the way Market Facts identified eligible respondents for this study.

Tables $2 \mathrm{a}$ and $2 \mathrm{~b}$ present key characteristics for this sample ("CMP" refers to the Consumer Mail Panel) and for the comparable NJPS households. The NJPS findings are weighted in two ways: by weights supplied by the survey research company (ICR, Inc.) to take into account sample biases related to major socio-demographic characteristics; and, to replicate the CMP sample design, households with teenagers present were assigned weights such that they constituted one half the sample (as they do, approximately, in the CMP sample). For gender-specific frequencies on age, education, and marital status (where information was available on respondent and spouse), no further weights were needed. However, the two samples differ in that all Jewish individual adults had an equal chance (theoretically) of entering the CMP sample, while the NJPS sample, when weighted, represents households and not individuals. Thus, to convert the NJPS subsample's results reported only by respondents (e.g., attendance at a Seder) to individual level statistics, the analysis multiplied the weights enumerated above by the number of Jewish household heads (one or two). In a 
Table 2a. Comparison of NJPS Subsample with Consumer Mail Panel Sample on Selected Variables: Percentage Disttributort

\begin{tabular}{|c|c|c|c|c|}
\hline \multicolumn{5}{|l|}{ REGION } \\
\hline & \multicolumn{2}{|r|}{ NJPS } & \multicolumn{2}{|c|}{ CMP } \\
\hline Northeast & \multicolumn{2}{|r|}{47} & \multicolumn{2}{|c|}{47} \\
\hline Midwest & \multicolumn{2}{|r|}{12} & \multicolumn{2}{|c|}{12} \\
\hline South & \multicolumn{2}{|r|}{19} & \multicolumn{2}{|c|}{21} \\
\hline West & \multicolumn{2}{|r|}{21} & \multicolumn{2}{|c|}{21} \\
\hline \multicolumn{5}{|l|}{ AGE } \\
\hline & \multicolumn{2}{|c|}{ Men } & \multicolumn{2}{|c|}{ Women } \\
\hline & NJPS & CMP & NJPS & CMP \\
\hline $50+$ & 9 & 13 & 5 & 7 \\
\hline $40-49$ & 50 & 61 & 43 & 54 \\
\hline $30-39$ & 37 & 25 & 48 & 37 \\
\hline Under 30 & 3 & 1 & 5 & 2 \\
\hline
\end{tabular}

MARITAL STATUS

\begin{tabular}{lcccc} 
& \multicolumn{2}{c}{ Men } & \multicolumn{2}{c}{ Women } \\
Married & NJPS & CMP & NJPS & CMP \\
Divorced/Sep & 97 & 95 & 96 & 80 \\
Widowed & 3 & 4 & 3 & 17 \\
& 0 & 1 & 1 & 3
\end{tabular}

EDUCATION

\begin{tabular}{|c|c|c|c|c|}
\hline & \multicolumn{2}{|c|}{ Men } & \multicolumn{2}{|c|}{ Women } \\
\hline & NJPS & CMP & NJPS & CMP \\
\hline Graduate Degree & 45 & 47 & 31 & 39 \\
\hline B.A. & 32 & 27 & 21 & $26^{\circ}$ \\
\hline Less & 24 & 26 & 39 & 36 \\
\hline
\end{tabular}

- Rexpondents eligible for NJPS aubample (unweighted N=381) conaisted of those who anwered "Jewith" for their current religion or that of their apouses, and who reported the presence in the household of a child 4-17. All rewult here are weighted, using the "houschold weights" wpplied by the data collection company. In addition, rexults for individuals which are not broken down by $2 x$ have been weighted by the number of Jewish adults in the houschold. To illuntrate, Table $2 \mathrm{~b}$ reports that $88 \%$ of Jewiah adults in this NJPS aubsample were in homes that umally lit Hanuktah candies, a figure somewhat higher than the proportion of homes that did 20 . 
manner of speaking, NJPS households with two adult Jews present voted twice; those with only one (primarily mixed married and single parent households) voted only once.

Table 2b. Further Comparisons of NJPS Subsample with CMP Panel Sample on Selected Variables: Percentage Distributiont

\begin{tabular}{|c|c|c|}
\hline & NJPS & CMP \\
\hline \multicolumn{3}{|l|}{ Household Income } \\
\hline$\$ 80,000+$ & 27 & 30 \\
\hline$\$ 60,000-79,999$ & 22 & 22 \\
\hline$\$ 40,000-59,999$ & 27 & 28 \\
\hline Under $\$ 40,000$ & 25 & 19 \\
\hline \multicolumn{3}{|l|}{ Jewish schooling as a child } \\
\hline Day school & 14 & 8 \\
\hline Part-time school & 40 & 40 \\
\hline Sunday school once a week & 20 & 25 \\
\hline None or just tutoring & 25 & 28 \\
\hline Married to a Jew & 70 & 64 \\
\hline Most friends Jewish & 50 & 41 \\
\hline \multicolumn{3}{|l|}{ Always or usually: } \\
\hline Lights Hanukkah candles & 88 & 93 \\
\hline Participates in Passover Seder & 82 & 81 \\
\hline Fasts Yom Kippur & 67 & 61 \\
\hline Lights Sabbath candles & 31 & 25 \\
\hline Has meat \& dairy sets of dishes & 16 & 17 \\
\hline Synagogue member & 60 & 60 \\
\hline Attends High Holiday services & 73 & 75 \\
\hline Attends services monthly or more & 37 & 31 \\
\hline Jewish organization member & 34 & 30 \\
\hline Been to Israel & 25 & 28 \\
\hline \multicolumn{3}{|l|}{ Denomination of respondent } \\
\hline Orthodox & 9 & 6 \\
\hline Conservative, Reconstructionist & 33 & 32 \\
\hline Reform & 45 & 37 \\
\hline Other & 14 & 25 \\
\hline
\end{tabular}

- See note to Table $2 a$. 
Notwithstanding some noticeable differences, the socio-demographic and Jewish identity characteristics of this sample generally resemble those for the NJPS subsample. Among the smaller differences are those relating to region of the country, men's education, men's marital status, income, lighting Hanukkah candles, Passover seder attendance, Yom Kippur fasting, lighting Sabbath candles, synagogue membership, belonging to a Jewish organization, and having traveled to Israel, and religious denomination. Somewhat larger differences are found elsewhere: more CMP women have a graduate degree; fewer CMP members went to day school and more attended once-a-week Sunday schools; more CMP women were divorcees and fewer were married; more CMP members were mixed married and fewer reported mostly Jewish friends. The most significant difference between the two samples is that CMP members are older-more are in their forties and fewer are in their thirties. The age difference helps explain why more CMP women are divorced.

In sum, in terms of Jewish identity characteristics, this sample is about as involved as the NJPS subsample, or, in a few instances (intermarriage most prominently), somewhat less involved. Some demographic differences are noticeable, especially with respect to age where the CMP sample is a few years older.

The extent to which these demographic variations affect the results is unknowable. In other ares of research, sampling variations and biases tend to have less impact on correlations and relationships between variables than on frequencies. Moreover, no compelling theory suggests why the sorts of differences noted here should affect the key concern of this paper, i.e., the impact of Jewish education. For example, the older and younger members of this sample report nearly identical patterns of results with respect to the impact of Jewish education on Jewish identity. In addition, where the results here overlap with those reported in the earlier studies, the findings here, in their substance, replicate rather than contradict them.

Clearly, from a sampling point of view, these data are less than ideal. If we take the NJPS as authoritative, the number of variations at least raises the possibility of some unknown bias. On the other hand, these data do offer the possibility for undertaking analyses that are impossible with the limited, but certainly more representative NJPS data set. The results here, then, can be seen as valuable, but need to be treated with caution.

The adult respondents reported on their parents' Jewish involvement, their own childhood Jewish education, their current involvement 
as Jewish adults, and their children's Jewish education. The teenagers' questionnaire included a small number of questions on current Jewish involvement that formed the basis of an index of their Jewish involvement.

By linking the teenagers' responses with those of their parents, the analysis examines three generations of Jews: the parents of the adult respondents, the adults themselves, and the teenagers. To be clear, the analysis of adults reports on all the adults, including parents of younger children. The portion focusing on the teenagers includes only their own parents, constituting less than half the adult sample.

The large number of cases within the relevant age groups permits analyses of certain critical subgroups (e.g., graduates of non-Orthodox day schools). In addition, the data set contains excellent and comprehensive information on parental variables. In the case of the adults, we have a very large battery of questions on their mothers and fathers. In the case of the teenagers, we have their own parents answering direct questions on their practices, affiliations, and attitudes.

The design allows us to examine whether findings concerning the impact of education can be generalized beyond one period or generation. Given all the changes over the last thirty years, researchers have exercised extreme caution about generalizing from the patterns among today's adults (whose childhood Jewish education took place at least 20 years ago) to the likely impact of current Jewish education 20 years from now. From a policy point of view, the ideal study would reveal the impact of today's Jewish education upon adult Jewish identity in the distant future. Obviously, that study lies beyond the realm of the feasible. Short of that ideal, we can examine the two most relevant generations simultaneously: today's younger adults, and their teenage children. That is, we can examine the long-range impact of Jewish education experienced in the distant past, and the short-range impact of Jewish education experienced quite recently. Should the results for the two generations coincide (as we shall see they do), we can feel more confident in drawing inferences about the likely impact of today's Jewish education in the future.

\section{MEASURES AND METHODOLOGY}

The analysis developed summary measures of Jewish involvement for three generations of individuals: the teenagers, the adults (the teenagers' parents plus parents of younger children), and the adults' parents (i.e., the grandparents of the teenagers and younger children of 
their generation). The teenagers and adults reported on themselves. The information on the adults' parents (the so called "grandparents") derived from reports of the adult respondents. Presumably, self-reports by the adults and teenagers on their own current behavior and attitudes are more reliable than the adults' reports on their parents' behavior and attitudes some $20-40$ years ago.

Students of modern Jewish identity have not come to a clearcut consensus on the meaning of Jewish identity. However, this lack of conceptual clarity has not prevented quantitatively oriented social scientists from developing what has become a traditional set of measures of Jewish identity (see, for example, Cohen 1983 and 1988; Goldscheider 1986; Goldstein and Goldscheider 1968). The measures used here fit within the general parameters of that research tradition.

The items included in the composite indices of Jewish involvement for the adults and their parents overlap to some extent. The parents' index contains items pertaining to attending a Passover Seder, lighting Hanukkah candles, using separate dishes for meat and dairy, lighting Sabbath candles, not having a Christmas tree, and belonging to a Jewish organization. In addition, the index incorporated parents' denomination, awarding more "points" for more denominational traditionalism(Orthodoxy $=3 ;$ Conservatism $=2 ; \operatorname{Reform}=1$; other $=0$ ).

The composite index of adult respondents' Jewish involvement included questions on: attending a Passover Seder, lighting Hanukkah candles, using separate dishes for meat and dairy, lighting Sabbath candles, fasting on Yom Kippur, attending High Holiday services, attending service monthly, not having a Christmas tree, not celebrating Christmas in any way, attachment to Israel, planning to visit Israel in three years, stated importance of "being Jewish ... in your life," belonging to a synagogue, belonging to a Jewish Community Center, attending JCC programs and having mostly Jewish friends.

The teenagers' index of Jewish involvement incorporated six questions on: the importance of being Jewish, attachment to Israel, attending High Holiday services, fasting on Yom Kippur, having mostly Jewish friends, and commitment to dating mostly Jews.

Each index was constructed by adding a single point for each item (except with respect to parents' denomination). Preliminary analyses used standardized versions of these indices as the principal dependent variables. The final results presented below present dichotomized measures, that is, the percent scoring high on Jewish involvement for adults and for teenagers. 
"High" for teenagers was set equivalent to scoring on four or more of the six items. As a result, of the high group, $97 \%$ fasted on Yom Kippur, $83 \%$ date mostly or only Jews, $82 \%$ say being Jewish is very important to them, $73 \%$ had mostly Jewish close friends, $62 \%$ felt very or extremely attached to Israel, and $48 \%$ attended religious services several times a month or more.

Among the adults defined as "high," on the Jewish involvement index, over $90 \%$ reported: synagogue membership, always having a Seder, always lighting Hanukkah candles, attending High Holiday services, fasting on Yom Kippur, and never having a Christmas tree (or celebrating Christmas in any other way). At least two-thirds had mostly Jewish friends, attended synagogue monthly, usually lit Sabbath candles, and belonged to a Jewish organization.

Substantively, almost all results for the dichotomous dependent variables replicate those using the standardized version; the former (percent scoring high) were retained below for ease of interpretation and presentation. (The one exception-entailing the impact of the Israel trip-is noted and explained below.) When incorporated in the Multiple Classification Analysis, parents' (i.e., the "grandparents") and the current adults' involvement were recoded into 7- and 6-point indices, respectively.

As noted earlier, denominational upbringing and parental inmarriage alone (the two parent-related variables available on the NJPS) cannot adequately represent parental Jewish involvement. Indeed, for adult respondents in this study, these two variables explain just $11 \%$ of the variance in the composite measure of Jewish involvement as opposed to $18 \%$ when using the parental index of Jewish involvement constructed out of the five ritual items, organizational membership, as well as denomination. (On the other hand, adding parents' rituals to denomination raised does nothing to increase the ability to predict the likelihood of intermarriage.) Denomination raised is a very powerful predictive variable, possibly the most valuable single variable of its kind. Nevertheless, the addition of other information on parents' household can, in some cases, dramatically improve the ability to predict certain Jewish identity characteristics.

Clearly, previous studies that relied on such limited information about respondents' parents were understating the influence of parents' Jewish involvement (since it was so poorly measured) and overstating that of Jewish schooling (since it, in a sense, illegitimately inherited the unmeasured influence of parental Jewish involvement). Logically, the superior measures of parental Jewish involvement here diminish the 
extent to which education is falsely credited with impact that properly must be attributed to the parental home. Any remaining random errors in measuring parental involvement-which cannot be ruled out entirely-lead to over-estimates of the impact of Jewish education.

The analysis examines the impact of two dimensions of Jewish education: schooling and informal education. With respect to schooling, respondents were classified according to the most intensive form of Jewish schooling they received, provided they attended a minimum number of years (five years for day schools, three for other schools). This procedure yields five groups: those who attended 1) Orthodox day schools, 2) non-Orthodox day schools, 3) part-time schools, 4) Sunday schools, and 5) those who had no schooling. (The final analysis-whose results are presented below-ignored the impact of private tutoring, an educational experience typically associated with preparation for the Bar or Bat Mitzvah ceremony. Preliminary analyses demonstrated little or no impact of tutoring net of parental involvement and other forms of Jewish education.)

The main branches of informal Jewish education in the United States include Israel travel, youth groups, and educationally intensive summer camping sponsored by religious institutions and Zionist youth movements. Owing to a defect in the questionnaire design, the analysis was forced to exclude camping. The single survey question on Jewish summer camping did not successfully distinguish those who attended camps with large Jewish enrollments and only a smattering of Jewish programming, from those who attended the handful of educationally intensive Jewish camps. As a result, the impact of Jewish camping could not be addressed in this study.

Several tables below examine the relationship between Jewish education and Jewish involvement. These are presented for parents and teenagers, both before and after adjusting for parental Jewish involvement and other control variables. The latter (adjusted) figures represent the extent to which high Jewish involvement scores (or the likelihood of intermarrying) for a particular type of schooling differ from the omitted category, those with no Jewish schooling; in the case of the dichotomous variables (youth group and Israel travel), the entries represent the difference in Jewish involvement between participants and non-participants.

In addition to variables noted above, the analyses control for age, region (living in the Western United States), and socio-economic status (as measured by a composite of adult respondents' education and 
income). Generally, older adults were more Jewishly involved, as were those who live outside the West, and those with higher SES.

\section{FINDINGS}

The Jewish involvement scores of adults and teenagers are arrayed in an order almost uniformly corresponding to intensity of Jewish education (Table 3). Among the categories of Jewish schooling, Orthodox day school alumni (or students) score the highest by

Table 3. Percent Scoring "High" on Jewish Involvement Indices' for Adults and for Teenagers and Percent Mixed Married for Adults by Type of Jewish Schooling and By Informal Jewish Education

\begin{tabular}{|c|c|c|c|c|c|}
\hline Type of Je & None & $\begin{array}{l}\text { Sunday } \\
\text { School }\end{array}$ & $\begin{array}{l}\text { Part- } \\
\text { Time }\end{array}$ & $\begin{array}{c}\text { Non-Orth. } \\
\text { Day }\end{array}$ & $\begin{array}{l}\text { Orth. } \\
\text { Day }\end{array}$ \\
\hline \multicolumn{6}{|c|}{ High on Index } \\
\hline Adults & $15 \%$ & $14 \%$ & $32 \%$ & $50 \%$ & $83 \%$ \\
\hline $\mathbf{N}$ & 371 & 330 & 529 & 20 & 81 \\
\hline Teenagers & $7 \%$ & $17 \%$ & $31 \%$ & $59 \%$ & $97 \%$ \\
\hline $\mathbf{N}$ & 153 & 157 & 253 & 39 & 37 \\
\hline \multicolumn{6}{|c|}{ Mixed Marrieds } \\
\hline Adults & $45 \%$ & $52 \%$ & $23 \%$ & $21 \%$ & $9 \%$ \\
\hline $\mathbf{N}$ & 338 & 303 & 497 & 19 & 78 \\
\hline \multicolumn{6}{|c|}{ Informal Jewish Education } \\
\hline & \multicolumn{3}{|c|}{ Youth Group } & \multicolumn{2}{|c|}{ Israel Trave } \\
\hline & No & Yes & & No & Yes \\
\hline \multicolumn{6}{|c|}{ High on Index } \\
\hline Adults & $19 \%$ & $31 \%$ & & $22 \%$ & $50 \%$ \\
\hline $\mathbf{N}$ & 581 & 810 & & 1,262 & 202 \\
\hline Teenagers & $4 \%$ & $40 \%$ & & $22 \%$ & $60 \%$ \\
\hline $\mathbf{N}$ & 252 & 354 & & 521 & 88 \\
\hline \multicolumn{6}{|c|}{ Mixed Married } \\
\hline Adults & $40 \%$ & $33 \%$ & & $37 \%$ & $27 \%$ \\
\hline $\mathbf{N}$ & 476 & 747 & & 1,061 & 185 \\
\hline
\end{tabular}

${ }^{1}$ The indices for adults and for teenagers consist of different items. 
far, followed by the non-Orthodox day school group, those who attended part-time schools, the Sunday school students, and those with no schooling. (The one exception: adults who attended Sunday School score lower than those who attend no school.) Similarly, for both adults and teenagers, participation in youth groups and Israel travel are each associated with higher levels of Jewish involvement. Intermarriage frequencies-which are obviously available for adults but not for teenagers-show similar relationships with education: more Jewish education is associated with lower rates of intermarriage.

These simple tabulations replicate those found in previous studies of this phenomenon: more Jewish education (except for Sunday school attendance by adults) is seemingly linked with higher levels of Jewish

Table 4. Percentage Distributions of Jewish Schooling, Youth Group Participation, and Israel Travel by Parents' Jewish Involve ment for Adults and for Teenagers

\begin{tabular}{|c|c|c|c|}
\hline & \multicolumn{3}{|c|}{ Adults } \\
\hline Their parents' & High & Mod & Low \\
\hline $\begin{array}{l}\text { Day School } \\
\text { Part Time } \\
\text { None \& Sunday }\end{array}$ & $\begin{array}{l}25 \\
57 \\
18\end{array}$ & $\begin{array}{c}3 \\
52 \\
46\end{array}$ & $\begin{array}{c}0 \\
28 \\
72\end{array}$ \\
\hline $\begin{array}{c}\text { Youth Group } \\
\text { Israel Travel } \\
\mathbf{N}\end{array}$ & $\begin{array}{c}73 \\
24 \\
271\end{array}$ & $\begin{array}{c}72 \\
17 \\
431\end{array}$ & $\begin{array}{c}50 \\
10 \\
629\end{array}$ \\
\hline & \multicolumn{3}{|c|}{ Teenagers } \\
\hline $\begin{array}{l}\text { Their parents' } \\
\text { Jewish involvement: }\end{array}$ & High & Mod & Low \\
\hline $\begin{array}{l}\text { Day School } \\
\text { Part Time } \\
\text { None\&Sunday }\end{array}$ & $\begin{array}{l}33 \\
49 \\
18\end{array}$ & $\begin{array}{r}4 \\
48 \\
48\end{array}$ & $\begin{array}{c}3 \\
18 \\
79\end{array}$ \\
\hline $\begin{array}{c}\text { Youth Group } \\
\text { Israel Travel } \\
\mathbf{N}\end{array}$ & $\begin{array}{c}79 \\
34 \\
179\end{array}$ & $\begin{array}{c}60 \\
8 \\
282\end{array}$ & $\begin{array}{c}22 \\
3 \\
144\end{array}$ \\
\hline
\end{tabular}


involvement. Of course, we cannot readily attribute causality to this simple association without first taking into account significant confounding factors, of which parental Jewish involvement is the most influential.

Indeed, the patterns of Jewish education vary closely with the level of the respective parents' Jewish involvement (Table 4). Those from more Jewishly involved homes experienced more intensive Jewish schooling. To illustrate, of adults whose parents were the most involved in Jewish life ("High" in Table 4), almost a quarter attended day schools, as contrasted with hardly any among those who reported only moderate or low levels of Jewish involvement on the part of their parents. Among those with moderately involved parents, just over half report more than Sunday school or no education, as contrasted with only $28 \%$ of those whose parents scored low on Jewish involvement.

As with schools, so with youth group participation and Israel travel; participation rates in both are also closely associated with parental Jewish involvement. Those adult respondents whose parents had high involvement were much more likely than those with the least involved parents to report participation in youth groups (73\% versus $50 \%)$, and they were over twice as likely to report having visited Israel as a youngster (24\% versus 10\%). Adult respondents with moderately involved parents reported intermediate frequencies of participation in youth groups and Israel travel.

The association between parental Jewish involvement and intensivity of Jewish education is even stronger among the teenagers. Moving from low, to moderate, to high levels of parental Jewish involvement, we find that day school utilization rises from $3 \%$ to $4 \%$ to $33 \%$; youth group participation jumps from $22 \%$ to $60 \%$ to $79 \%$; and Israel travel surges from $3 \%$ to $8 \%$ to $34 \%$.

In light of the close connection between parents' Jewishness and their children's education, and in light of the substantial impact of parental Jewish involvement upon the child's involvement, a major portion of the association between childhood Jewish education and current involvement must be attributed to the link between parental involvement and intensivity of Jewish education. We cannot estimate the impact of Jewish education upon current Jewish involvement without first extracting the influence of parental Jewish involvement that underlies, influences, and chronologically precedes both factors.

Using Multiple Classification Analysis, we can take account of the confounding influences of parental involvement as well as other related factors (e.g., age, sex, socio-economic status, and region). With 
respect to youth groups, the analysis also controls for type of Jewish schooling, an event which typically precedes teenage participation in youth groups. For similar reasons, the computation of the net impact of adolescent Israel travel (which usually takes place at age 16 or 17) controls for both schooling and youth groups. (Almost all Israel travelers belonged to youth groups, and a disproportionate number attended day schools. The estimate of the impact of the Israel experience needs

Table 5. The Impact of Jewish Education on Jewish Involvement: Percent Scoring High on Jewish Involvement by Type of Jewish Schooling and by Informal Jewish Education for Adults and for Teenagers Adjusting for Their Parents' Jewish Involvement, Age, Sex, SES, Region (West), and Prior Jewish Educational Experience' (Multiple Classification Analysis)

Impact of Type of Jewish Schooling (vs. none)

$\begin{array}{lcccc} & \text { Sunday } & \begin{array}{c}\text { Part- } \\ \text { Time }\end{array} & \begin{array}{c}\text { Non-Orth. } \\ \text { Day }\end{array} & \begin{array}{c}\text { Orth. } \\ \text { Day }\end{array} \\ \text { Adults } & & \text { Time } & 31 & 48 \\ \text { Teenagers } & -1 & 10 & 32 & 55\end{array}$

Impact of Informal Jewish Education

$\begin{array}{lcc} & \begin{array}{c}\text { Youth Group } \\ \text { vs. none }\end{array} & \begin{array}{c}\text { Israel Travel } \\ \text { vs. none }\end{array} \\ \text { Adults } & 7 & 15 \\ \text { Teenagers } & 9 & 14\end{array}$

Note: The numerical entriea represent the differences between the particular category and those with no Jewinh achool, or no youth group participation, or no Inrel experience. For example, the far right number in the top row means that graduates of Orthodox day schools have a 48 per cent higher chance of reporting high levels of Jewith involvemem today a compared with no Jewith achooling, after controlling for differences that one would anticipate on the basis of parental Jewiah involvement, SES, age, and other control variables.

- Reaults for youth group also adjuat for type of Jewirh schooling. Reaults for Iarael travel also adjux for type of Jewish echooling and youth group participation. Schooling entries are deviations from the mean of those with no formal Jewiah achooling. Youth group and Inrel travel entries represent the adjusted differences between those reporting and not reporting these experiences. The indices for adults and for teenagers coneint of different items. 
to remove the confounding of these prior educational experiences as well.)

Overall, when compared with the simple crosstabulations presented earlier, the findings point to a significantly diminished impact of Jewish education as a result of controlling for these factors (Table 5). Significantly, the patterns for adults and teenagers generally resemble one another.

The scores of Sunday school students (-1 point for adults) suggest little if any impact of this type of Jewish education upon Jewish identity. (A score of -1 means that, all other things being equal, those who attended Sunday schools were one percentage point less likely to emerge as highly involved Jewish adults than were those with no Jewish education.) In contrast, the part-time school graduates display a modest positive impact of their schooling (10 points for the adults and 10 for the teenagers). The non-Orthodox day schools score far higher (31 and 32 points for adults and teens respectively). The Orthodox day school alumni substantially outscore the others: 48 for the adults, and 55 for the teenagers. In other words, the net impact of Sunday schools on high Jewish involvement as an adult is negligible; that of part-time schools, on average, is slightly positive; that of nonOrthodox day schools, substantially greater; and of Orthodox day schools, even greater still.

Beyond schools, both youth groups and adolescent Israel travel are associated with increments in Jewish involvement, even after controlling for parents' Jewish involvement, Jewish schooling, and other factors. Controlling for those factors, youth group participation increases the chances of high involvement in Jewish life by 7 points for adults, and 9 points for teenagers. The Israel visit in one's youth seems to bring with it a 15 percent increment in the chances of scoring high on Jewish involvement, above and beyond the home, Jewish schooling, youth groups and other factors. The teenagers' net Israel travel effect amounted to a nearly identical 14 percentage points.

The results in Table 5 may exaggerate the impact of Israel experience. Here the results suggest that the Israel experience is clearly more influential that part-time schools, though less than non-Orthodox day schools. In point of fact, more detailed analysis (not shown) of the individual items in the Jewish involvement indices demonstrated that Israel travel affects Israel attachment much more than ritual practice, communal affiliation and association (a pattern borne out in the results for intermarriage presented immediately below). In addition, use of standardized versions of the dependent variables (i.e. adults' and 
teenagers' Jewish involvement scores) demonstrated that the impact of the Israel experience drew even with that of part-time schools and youth groups. When combined with the findings in Table 5 , this pattern may mean that Israel trips work well to foster entry into the upper reaches of Jewish involvement but that it does less to raise overall levels of involvement.

To summarize the key findings thus far, relative to those with no Jewish education, almost all forms of Jewish education contribute to higher levels of Jewish involvement. Sunday school is the one clear exception to this generalization. The part-time school, youth group, adolescent Israel travel, each make modest contributions to subsequent Jewish involvement. Day schools, be they Orthodox or not, typically exert much greater impact than that of the other instruments.

Table 6. The Impact of Jewish Education on Intermarriage: Percent Married to Non-Jews by Type of Jewish Schooling and by Informal Jewish Education for Adults and for Teenagers Adjusting for Their Parents' Jewish Involvement, Age, Sex, SES, Region (West), and Prior Jewish Educational Experience" (Multiple Classification Analysis)

Impact of Type of Jewish Schooling (vs. none)

$$
\begin{array}{cccc}
\text { Sunday } & \text { Part- } & \text { Non-Orth. } & \text { Orth. } \\
& \text { Time } & \text { Day } & \text { Day } \\
8 & -11 & -19 & -20
\end{array}
$$

Impact of Informal Jewish Education

$\begin{array}{cc}\text { Youth Group } & \text { Israel Travel } \\ \text { vs. none } & \text { vs. none } \\ -5 & -5\end{array}$

Note: Entries are differences between the particular calegory and those with no Jewich school, or no youth group participation, or no Imrael experience.

- Reaults for youth group also adjust for type of Jewish schooling. Results for Inrel travel also adjust for type of Jewiah schooling and youth group participation. Schooling entries are devintions from the mean of those with no formal Jewith schooling. Youth group and Israel travel entries represent the adjusted differences between those reporting and not reporting these experiences. 
Beyond whatever impact Jewish education may exert upon Jewish involvement generally is the question of whether and to what extent it influences the likelihood of intermarriage in particular. Controlling for parents' Jewish involvement, age, sex, social status and region (Jews in the West report higher rates of intermarriage), several forms of education do appear to diminish the chances of intermarriage. (The mixed marriage rate in this sample is $35 \%$.) Controlling for other factors, alumni of part-time schools were eleven percentage points less likely to intermarry than those with no Jewish schooling (Table 6). Alumni of day schools were even more likely to marry within the faith (a net difference of 19 points for non-Orthodox day schools and 20 points for the Orthodox). Again, Sunday schools stand out as an exception. Those with a Jewish education no more intensive than the Sunday School actually report eight percent more frequent intermarriage than do those with no Jewish schooling.

To understand this counter-intuitive finding, we need to recall that Sunday schools in the previous generation were most often associated with the Reform movement. Affiliates of this movement then, as now, tended to reside in areas where the Jewish population is relatively more sparse, and where in-marriage rates are lower. As a result, attendance at a Sunday school is, in all likelihood, associated with residence in areas of low Jewish density which are in turn associated with reduced chances of Jewish-Jewish marriage.

Youth groups and Israel travel exerted far less influence upon inmarriage probabilities than did Jewish schooling. Youth group participation, net of other factors (including parents' involvement and Jewish schooling) diminished intermarriage chances by only five percentage points, the same as travel to Israel. In contrast with the results for Jewish involvement, where informal education exerts a stronger impact than part-time schools, intermarriage seems to be affected more by schooling than by youth group participation or Israel travel.

Mixed married Jews are far less active in conventional Jewish life than the in-married (see, for example, Medding, Tobin, Fishman and Rimor 1992). The relationship established above between Jewish education and intermarriage suggests the possibility that the impact of Jewish education upon Jewish involvement is largely a function of its impact upon intermarriage. That is, we need to examine whether higher levels of Jewish education are still associated with higher levels of Jewish involvement, even after controlling for type of marriage (by dividing the sample into in-married and mixed married subsamples). 
Perhaps the influence of education on involvement operates primarily through choice of spouse.

Table 7. The Impact of Jewish Education on Jewish Involvement Among In-married and Intermarried Adults: Percent Scoring High on Jewish Involvement by Type of Jewish Schooling and by Informal Jewish Education for In-married and Intermarried Jewish Respondents Adjusting for Their Parents' Jewish Involvement, Age, Sex, SES, Region (West), and Prior Jewish Educational Experience" (Multiple Classification Analysis)

Impact of Type of Jewish Schooling (vs. none)

$\begin{array}{lcccc} & \text { Sunday } & \text { Part- } & \text { Non-Orth. } & \text { Orth. } \\ \text { In-Married } & & \text { Time } & \text { Day } & \text { Day } \\ \text { Mixed Married } & 2 & 10 & - & 49 \\ \text { Impact of Informal Jewish Education } & - & - \\ & \text { Youth Group } & \text { Israel Travel } \\ \text { vs. none } & \text { vs. none } \\ \text { In-Married } & \mathbf{8} & 18 \\ \text { Mixed Married } & 3 & 7\end{array}$

* Remults for youth group also adjunt for type of Jewinh schooling. Rezults for Inrael travel also adjust for type of Jewish achooling and youth group paricipation. Schooling entries are deviations from the mean of those with no formal Jewish schooling. Youth group and lanel travel entries represent the adjunted differences between those reporting and not reporting these experiences.

Table 7 presents the differences in the percent scoring high on indices of Jewish involvement, controlling for parents' Jewish involvement and other variables, for in-married and mixed married adults, tabulated separately. The results point to the persistence of the sorts of effects seen earlier for the in-married. However, among the mixed marrieds, the seeming impact of Jewish education, both formal and informal, is markedly reduced.

\section{CONCLUSIONS}

The evidence supports the view that most instruments of Jewish education raise subsequent levels of Jewish involvement. Sunday 
schools, possibly because of the minimal amount of time and commitment they entail, are the single exception to this generalization. At the other extreme, Orthodox day schools seem to produce the most marked net increase in Jewish involvement of any form of Jewish education. Clearly, even non-Orthodox day schools "work;" but Orthodox day schools work even better.

Why Orthodox day schools excel is a matter for speculation. Their exceptional impact might be due to stronger parental involvement, or to longer hours and years in Jewish school characteristic of the Orthodox population, or to still other factors that are distinctive to Orthodoxy and its schools. These data cannot satisfactorily distinguish among these alternative explanations. Almost all the Orthodox day school students attend(ed) through high school; almost all the others ceased their Jewish day school studies before then.

Contrary to earlier studies, the findings here support the view that even part-time schools that meet more than once a week exert a moderate impact on Jewish involvement. In addition, youth groups and Israel trips as an adolescent also seem to be associated with increments in Jewish involvement, although they have little impact upon the chances of marrying within the group.

The effects of Jewish education persist beyond marriage. It increases the chances that Jews will marry Jews; and, if they marry Jews (but not Gentiles), Jewish education elevates the likelihood that as adults they will be more involved in Jewish life.

The conclusions drawn here regarding the effectiveness of Jewish education can be taken with a greater degree of confidence than those emerging from earlier studies for a number of reasons. One consideration is that this data set permits more precise, accurate, and comprehensive measures of parents' Jewish involvement, a major confounding factor whose influence on their children's Jewish involvement may well have been mistakenly attributed to Jewish education in previous studies. In addition, this study drew upon analyses of two generations-younger to middle-aged adults and teenagers. The similarity in the findings for both generations suggests greater reliability in the substantive conclusions. Moreover, the large number of cases allowed for distinguishing between Orthodox and non-Orthodox day schools, further clarifying an issue that had been muddied in the past.

Truth be told, the estimates derived here for the impact of Jewish education upon Jewish identity are both too high and too low. They are too high in the sense that even these data do not permit a complete control of parental and community influences. In theory, the analysis 
held constant the parents' interest and involvement in Jewish life. In reality, even after controlling for holiday celebration, ritual involvement, Israel attachment, in-marriage, denomination, etc., one still has to suspect that parents who send their children to more intensive forms of Jewish education (such as day school) are somehow more Jewishly committed than those who do not. Moreover, parents' Jewish schooling choices also reflect something about the communities in which these schools are available, as well as the parents themselves. Parents who choose more intensive forms of Jewish education have also chosen to live in communities with a sufficient number of Jews interested in supporting intensive forms of Jewish education.

For these and other reasons, those children who experienced more intensive forms of Jewish education bring with them unmeasured (and possibly unmeasurable) parental and communal Jewish resources lacking in their counterparts. These unmeasured advantages may well explain some of the gaps between, say, day school and part-time school students (or between participants in Israel trips and youth groups versus those who participated in neither). In short, even in the best of circumstances, we cannot fully control for antecedent and confounding factors, and therefore we cannot guarantee a totally level statistical playing field in which to assess the true net impact of Jewish education on Jewish identity.

At the same time, this analysis may well have underestimated the impact of Jewish school, or, perhaps more precisely its potential impact. These results measured only the average influence of each major form of Jewish education. We had no information on the quality associated with each type of education. The analysis contained no information on issues related to teachers, curriculum, parental involvement in education, administrative excellence, school resources, community support and numerous other factors that the "school-effects" literature have shown to influence academic achievement. Presumably, this principle extends to the realm of Jewish education, although no systematic quantitative studies have related Jewish educational quality to outcome measures. Logically, those Jewish youngsters who attended weaker schools experienced, on average, a less profound impact upon their Jewish identity than those who went to "better" schools, however "better" is defined. Thus, the true measure of the impact of Jewish education needs to take into account not only the choice of major forms of Jewish education (the only feature of education available here) but its quality as well. Clearly, by itself, the quantitative, retrospective approach embodied in this paper is ill-suited to the important task of 
understanding how value-oriented education aiming at long-term impact succeeds or fails in its central mission.

Finally, evidence that many forms of Jewish education can be effective in developing Jewish identity and involvement as an adult speaks to the larger questions raised earlier regarding American ethnicity and American religious life. This evidence suggests that the persistence of ethnic attachment among an upper middle class white ethnic group and/or the intergenerational transmission of religious commitment among American liberal religious groups are at least feasible endeavors, though certainly still difficult. As such, this evidence serves to undermine the claim of those who would assert that the near inevitability either of the Melting Pot model for American ethnic groups, or of the continuation of the decline in more liberal religious groups experienced over the last quarter century.

\section{NOTES}

- This research was supported by a grant from the Joint Authority for Jewish-Zionist Education of the WZO and the JAFI. I express my gratitude to Sylvia Barack Fishman, Alice Goldstein, and Susan Wall for their helpful comments on an earlier version of this paper.

\section{REFERENCES}

Alba, Richard. 1985. Italian Americans: Into The Twilight of Ethnicity. Englewood Cliffs, N.J.: Prentice-Hall. - 1990. Ethnic Identity: The Transformation of White America. New Haven, CT: Yale University Press.

Bock, Geoffrey. 1976. "The Jewish Schooling of American Jews: A Study of Non-cognitive Educational Effects. " Ph. D. dissertation, Harvard University, Cambridge, MA.

Cohen, Steven M. 1974. "The Impact of Jewish Education on Religious Identification and Practice." Jewish Social Studies, 36: 316-326.

. 1983. American Modernity and Jewish Identity. New York: Methuen.

1988, American Assimilation or Jewish Revival? Bloomington:

Indiana University Press.

1994. "Why Intermarriage May Not Threaten Jewish Continu-

ity." Moment (December): 54ff. 
Cohen, Steven M. and Fein, Leonard J. 1985. From Integration to survival: American Jewish anxieties in transition. Annals of the American Academy of Political and Social Science 480, 75-88.

The Commission on Jewish Education in North America. 1990. A Time to Act. Lanham, MD: University Press of America.

Dashefsky, Amold and Shapiro, Howard M. 1974. Ethnic Identification Among American Jews. Lexington, MA: Lexington Books.

Finke, Roger and Rodney Stark. 1992. The Churching of America. New Brunswick: Rutgers University Press.

Fishman, Sylvia Barack and Alice Goldstein. 1993. When They are Still Grown, They Will Not Depart: Jewish Education and the Jewish Behavior of American Adults. Research Report \# 8. Waltham, MA: Brandeis University, Cohen Center for Modem Jewish Studies.

Gans, Herbert J. 1979. "Symbolic Ethnicity: The Future of Ethnic Groups and Cultures in America." Ethnic and Racial Studies 2: 120.

1994. "Symbolic Ethnicity and Symbolic Religiosity: Towards a Comparison of Ethnic and Religious Acculturation." Ethnic and Racial Studies 17: 576-592.

Glazer, Nathan and Moynihan, Daniel P. 1963. Beyond the Melting Pot. Cambridge, MA: MIT Press.

Glazer, Nathan \& Moynihan, Daniel P. (eds.) 1975. Ethnicity: Theory and Experience. Cambridge, MA: Harvard University Press.

Goldscheider, Calvin. 1986. Jewish Continuity and Change. Bloomington: Indiana University Press.

Goldstein, Alice and Sylvia Barack Fishman 1993. Teach Your Chidlren When They are Young: Contemporary Jewish Education in the United States. Research Report \# 10. Waltham, MA: Brandeis University, Cohen Center for Modern Jewish Studies.

Goldstein, Sidney and Calvin Goldscheider. 1968. Jewish Americans. Englewood Cliffs, N.J.: Prentice-Hall.

Greeley, Andrew M. 1974. Ethnicity in the United States: A Preliminary Reconnaissance. New York: John Wiley \& Sons.

Greeley, Andrew M. and Peter Rossi. 1966. The Education of Catholic Americans. Chicago: Aldine.

Himmelfarb, Harold. 1974. "The Impact of Religious Schooling: The Effects of Jewish Education Upon Adult Religious Involvement." Ph. D. dissertation, University of Chicago: Chicago, IL. . 1979. "Agents of Religious Socialization." The Sociological Quarterly 20: 477-494. 
Horowitz, Bethamie. 1993. The 1991 New York Jewish Population Study. New York: UJA-Federation.

Kosmin, Barry A., Sidney Goldstein, Joseph Waksberg, Nava Lerer, Ariella Keysar and Jeffrey Scheckner. 1991. Highlights of the CJF 1990 National Jewish Population Survey. New York: Council of Jewish Federations.

Lieberson, Stanley and Mary Waters. 1988. From Many Strands: Ethnic and Racial Groups in Contemporary America. New York: Russell Sage Foundation.

Lipset, Seymour Martin. 1994. "The Power of Jewish Education. " Los Angeles: Wilstein Institute of Jewish Policy Studies.

Mayer, Egon. 1993. "Jewish Education and Intermarriage Among American Jews: Some Demographic and Sociological Insights from the 1990 NJPS." Presented at the January 1993 Meeting of the International Steering Committee of the Association for Demographic Policy of the Jewish People.

Medding, Peter Y., Gary A. Tobin, Sylvia Barack Fishman and Mordechai Rimor. 1992. "Jewish Identity in Conversionary and Mixed Marriages," American Jewish Year Book: 3-76.

Novak, Michael. 1971. The Rise of the Unmeltable Ethnics. New York: MacMillan Publishing.

Rimor, Mordechai and Elihu Katz. 1993. "Jewish Involvement of The Baby Boom Generation: Interrogating the 1990 National Jewish Population Survey." Jerusalem, Israel: The Louis Guttman Israel Institute of Applied Social Research.

Roof, Wade C. and William McKinney. 1987. American Mainline Religion. New Brunswick: Rutgers University Press. 